\title{
Arabų sukilimai ir Vakarų saugumo interesai: žvilgsnis iš Lietuvos
}

$2011 \mathrm{~m}$. sausį arabų šalyse kilusi sukilimų (neginkluotų ir ginkluotų) banga yra fenomenalus reiškinys. Ne veltui jam tarptautinëje informacinëje erdveje skiriama ypač daug dèmesio. Iš tiesu panašaus masto politinių ir socialinių sukretimų arabų pasaulyje pastaraisiais dešimtmečiais nèra buvę. Neatsitiktinai daugelis Vakarų valstybių, kurių saugumo interesai buvo glaudžiai susiję su sukilimų apimtomis arabų šalimis, jiems prasidejjus jautėi sutrikusios. Sumišę buvo įvairūs arabų šalimis besidomintys Vakarų saugumo ekspertai. Dar prieš kelis mènesius iki sukilimų pradžios beveik niekas iš jų neprognozavo, kad artimiausiu metu arabų šalių laukia ypač dideli politiniai ir socialiniai sukrètimai, didžiuliai saugumo situacijos tam tikrose arabų šalyse ir atitinkamuose regionuose pokyčiai. Netikètai arabų sukilimų užklupti Vakarų saugumo ekspertai suskubo aiškintis, kokios tų sukilimų priežastys? Kokie veikëjai ir kokios jègos už jų stovi? Iškeltas svarbus klausimas - koks gali būti šiu arabų sukilimų poveikis Vakarų interesams? Ar sukilimų apimtose šalyse keičiasi tik valdantys asmenys? Ar vyksta gilesni sisteminiai (revoliuciniai) pokyčiai, turèsiantys ilgalaikį strategini poveikį Vakarams? Kol kas vienareikšmių atsakymų į šiuos klausimus nèra, nors tam tikras įžvalgas jau galima daryti. Straipsnyje yra analizuojami arabų sukilimai, jų priežastys, galimas poveikis Vakarų ir Lietuvos saugumo interesams. Keliamas klausimas - kaip arabų sukilimai veikia ir gali paveikti Lietuvos nacionalinio saugumo interesus? Kiek ịvykiai Tunise, Egipte, Libijoje, Sirijoje, Bahreine ir kitose arabų šalyse svarbūs Lietuvai? Ar iš tiesų galime ignoruoti tai, kas vyksta toli nuo Lietuvos sienų esančiuose regionuose?

\section{Ivadas}

Arabų valstybes arba Vidurio Rytų regioną ${ }^{1}$ sunku būtų vadinti tradiciniais Lietuvos akademinés bendruomenès atstovų domejjimosi objektais. İvykius arabų valstybèse analizuojantis ar tokios analizès siekiantis Lietuvos mokslinès bendruomenès atstovas rizikuoja likti nesuprastas. Kolegoms jis gali sudaryti šalies politinèse ir geopolitinèse realijose nesusigaudančio žmogaus ịspūdį.

Kita vertus, globalizacijos amžiuje Lietuvos akademinè bendruomenè negali

\footnotetext{
* Egidijus Gailiūnas - Vilniaus universiteto Tarptautinių santykių ir politikos mokslų instituto doktorantas. Adresas: Vokiečiu g. 10, 01130 Vilnius; tel. (8 5) 25 14130, el. paštas - gegidijus@gmail.com ${ }^{1}$ Šiame straipsnyje Šiaures Afrika ir Persijos įlanka yra laikomi Vidurio Rytų regiono subregionais. Šiam, plačiau nei paprastai suprantamam, Vidurio Rytų regionui yra priskiriamos valstybès teritorijoje nuo Mauritanijos iki Pakistano.
} 
apsiriboti ir iš tiesų neapsiriboja tik su valstybès vidaus politika bei kaimyninèmis šalimis susijusiais tyrimais. Suprantama, kad šiais laikais net geografiniu požiūriu tolimuose regionuose vykstantys politiniai įvykiai ir procesai gali labai greitai paveikti saugumo situaciją Lietuvoje, Europos Sąungoje ar NATO. 2001 m. rugsëjo $11 \mathrm{~d}$. teroristiniai išpuoliai Niujorke ir Vašingtone, Vakarų inicijuotos karinés intervencijos i Afganistaną ir Iraką skatina Lietuvos mokslinés bendruomenés atstovus daugiau dèmesio skirti naujo tipo grèsmèms (pavyzdžiui, terorizmui) ir Vidurio Rytų regionui. Turint omenyje pastaruosius pokyčius, tokių ịvykių, kaip arabų sukilimai, Lietuvos politologai ir tarptautinių santykių ekspertai negali nepastebėti. Pažymėtina, kad arabų sukilimai, kurie dar vadinami „,arabų pavasariu“, „arabų revoliucijomis“, „arabų pabudimu“, „intifadomis“, pastaraisiais ménesiais yra viena populiariausių diskusijų temų i̇vairių didžiųjų Vakarų valstybių akademiniuose sluoksniuose.

Arabų sukilimai nèra eilinis įvykis tarptautinëje politinejje arenoje ir arabų pasaulyje. $2011 \mathrm{~m}$. pradžioje Vidurio Rytuose kilę sukilimai lyginami su $1848 \mathrm{~m}$. Tautų pavasariu, 1989 m. ìvykusia Berlyno sienos griūtimi ir prasidejusiu Rytų Europos išsilaisvinimu nuo komunizmo, XXI a. pradžios „spalvotosiomis revoliucijos“. Tačiau, Habibo Maliko teigimu, istorinių analogijų arabų sukilimams paieškos yra bergždžias užsiẻmimas. Pasak jo, arabų sukilimai - unikalus reiškinys².

Vidurio Rytuose nuvilnijusi sukilimų banga visus užklupo netiketai. Panašu, kad net patys arabai jos nesitikejo. Todèl nèra keista, kad kol kas galima rasti palyginti nedaug arabų sukilimams skirtos mokslinès literatūros. Kol kas palyginti mažai yra analizuotas galimas arabų sukilimų poveikis Vakarų saugumo interesams. Iš esmès nèra jokio bent kiek rimtesnio arabų sukilimų poveikio Lietuvos saugumo interesams vertinimo.

Šio straipsnio tikslas - išsiaiškinti galimą arabų sukilimų poveikį Vakarų ir Lietuvos saugumo interesams. Kaip arabų sukilimai paveiks Vakarų interesus Vidurio Rytuose? Kiek įvykiai Tunise, Egipte, Libijoje, Sirijoje, Bahreine ir kitose arabų šalyse svarbūs Lietuvai? Ar tai, kas vyksta toli nuo valstybinių sienų, Lietuvos visiškai neliečia? Atsakymų i ǐiuos klausimus paieškos pradedamos nuo trumpos to, kas vadinama arabų sukilimais, apžvalgos.

\section{Arabụ sukilimų anatomija}

Arabų sukilimų poveikio Vakarų interesams analize sunkiai įsivaizduojama be pagrindinès informacijos apie jų pradžią, eigą, priežastis ir galimą poveikį

\footnotetext{
${ }^{2}$ Malik H., "Is It the Arab Spring?”, USA: Johns Hopkins University, 3003 2011, http://www.sais-jhu.edu/ bin/k/i/Is_It_The_Arab_Spring_30-3-11.pdf, 15042011.
} 
Vidurio Rytų regionui pateikimo. Taigi, ši straipsnio dalis yra savotiška arabų sukilimų anatomija. Tiesa, ji nèra ir negali būti išbaigta, nes arabų sukilimai yra tebevykstantys procesai.

Simboline arabų sukilimų pradžia galima laikyti 2010 m. gruodžio 17 dieną. Tą dieną Tuniso Sidi Buzido miestelio gyventojas Mohamedas Bouazizis, protestuodamas prieš jo gatves prekybos verslo žlugdymą ir žeminantị valdžios pareigūnų elgesį, nusprendè viešai susideginti ${ }^{3}$. Iš pirmo žvilgsnio toks Bouazizio veiksmas, kurị lèmé ekonominès ir socialinès nuoskaudos, atrodè politiškai mažai reikšmingas. Tai buvo vieno asmens nevilties aktas. Jis įvyko ne Tuniso sostinëje, bet palyginti nedideliame miestelyje. Tunise, ir apskritai, Vidurio Rytuose tai buvo ne pirmas atvejis, kai protesto vardan žmogus viešai susidegina ${ }^{4}$. Nè vienas prieš Bouazizị viešai susideginęs arabų protestuotojas nesusilaukè ypač didelio žiniasklaidos susidomèjimo. Tačiau Bouazizio nevilties aktas netikètai sukèlè politiškai ir strategiškai svarbių bei sunkiai prognozuojamų ịvykių, sukretusių visą Vidurio Rytų regioną, grandinę. Bouazizis tapo sukilimų prieš Vidurio Rytų regiono valstybèse įsitvirtinusius autokratinius režimus, kurie draudžia masinius protestus ir politinị aktyvumą apskritai, simboliu. Jo pasipriešinimo aktas paskatino didelio masto protestus Tunise, o pastarieji politinius neramumus teritorijoje nuo Mauritanijos iki Omano. Bouazizio dèka po kelių dešimtmečių pertraukos paprasti arabų valstybiu gyventojai vel pasijauté esantys aktyvūs politinio gyvenimo dalyviai ${ }^{5}$.

2011 m. sausį, po musulmonams svarbių penktadieninių maldų, Alžyre, Bahreine, Gazos ruože, Irake, Jemene, Maroke, Omane, Sirijoje pradetos rengti vadinamosios „pykčio dienos“ - demonstracijos prieš valdžią. Kovo pradžioje įvairaus pobūdžio politiniai neramumai vyko 16 iš 22 Arabų lygos šalių ${ }^{6}$. Sausio 14 dieną iš Tuniso prezidento posto dèl kilusių masinių protestų pasitraukè 23 metus šią šalị valdęs Zine'as El Abidine’as Ben Ali. Tuniso protestuotojų sẻkmés paskatinti egiptiečiai pasiekè, kad vasario $11 \mathrm{~d}$., po beveik 30 metų trukusio valdymo, iš Egipto prezidento posto atsistatydintų Hosnis Mubarakas.

Vidurio Rytų valstybes apèmę neramumai išgąsdino daugelị diktatorių, tačiau ne visiems jiems protestai baigesi taip skaudžiai kaip Ben Ali ir Mubarakui. Nedideli neramumai, kurie 2011 m. pradžioje užfiksuoti Irake, Jordanijoje, Maroke ir Omane, šių valstybių vadovams ypač didelių problemų nesukèlè. Politiniais

\footnotetext{
${ }^{3}$ Dèl patirtų sužalojimų Bouazizis $2011 \mathrm{~m}$. sausio 4 dieną ligoninëje mirè.

${ }^{4}$ Žr.: Ryan Y., "How Tunisia’s revolution began”, Al Jazeera English, 2601 2011, http://english.aljazeera.net/ indepth/features/2011/01/2011126121815985483.html, 03042011.

5 Corm G., "Is this an Arab spring?", Le Monde Diplomatique, 0604 2011, http://mondediplo. com/2011/04/02arabspring, 24052011.

${ }^{6}$ Fakhro E., Hokayem E., ,Waking the Arabs“, Survival, 53(2), April-May 2011, p. 21.
} 
neramumais Vidurio Rytuose rimtai susirūpinęs Saudo Arabiją valdantis Saudų klanas iš sudetingos situacijos irgi išsisuko. Saudų klanas kaip gynybos nuo protestuotojų priemones panaudojo „naftos dolerius“, vahabizmo ideologiją ir viduramžiškų bausmių taikymo, remiantis šariatu (arab. šaria) praktiką ${ }^{7}$. Tik prasidejus sukilimams Saudų klanas skyre dešimtis milijardų dolerių naujų gyvenamųju namų statybai, nedarbo lygio mažinimui ir sveikatos apsaugos sistemos gerinimui ${ }^{8}$.

2011 m. pradžioje daugelyje Vidurio Rytų valstybių protestus rengé paprasti civiliai gyventojai. Protestai dažniausiai vyko ir baigesi taikiai. Tačiau taip buvo ne visur. Kai kuriose Vidurio Rytų valstybese demonstracijos prieš valdžią baigesi autokratiniams režimams lojalių saugumo pajègų ir sukilèlių susiremimais. Vasario viduryje daugiau nei 40 metų šalį valdantis Muammaras Gaddafis nutare nesiremti Ben Ali ir Mubarako paliktu pavyzdžiu - taikiai atsisakyti valdžios. Gaddafis pasiryžo su jo valdymu nepatenkintais protestuotojais susidoroti jega. Tokio jo sprendimo rezultatas - šali i dvi stovyklas padalijęs pilietinis karas. Gaddafio pasirinktu keliu netrukus nuseke Sirijos prezidentas Bashiras Al-Assadas, 40 metu šią šalį valdančio Assadų klano atstovas. Jis prieš sukilusius Sirijos gyventojus, kurių didžioji dalis beginkliai civiliai, irgi pasiunte tankus. Tokią Gaddafio ir Al-Assado reakciją i politinių permainų siekiančius protestuotojus, galëjo paskatinti sẻkmingas Bahreino valdančiojo elito, kurị iš esmés sudaro sunitai, susidorojimas su šalies gyventojų daugumą sudarančiais ir tam tikrais valdžios sprendimais nepatenkintais šiitais.

$2011 \mathrm{~m}$. gegužę arabų sukilimai èmé strigti. Vidurio Rytų valstybes valdantys karaliai, emyrai ir sultonai pradejjo palyginti sèkmingą kontrpuolimą. Jo tikslas - užkirsti kelią valdžios pasikeitimams, panašiems ị ịvykusius Tunise ir Egipte. Sukilimai Vidurio Rytuose èmé slopti ir dèl vis labiau juntamo sukilelių nuovargio. Pastebimos tendencijos, kad sukileliai vis dažniau pradeda abejoti taikių protestų efektyvumu. Be to, prievartos naudojimas darosi beveik neatskiriamu naujų politinių protestų palydovu.

Arabų sukilimai neturi aiškių lyderių. Dauguma jų prasidëjo be nurodymus dalijančių organizacinių centrų ir griežto politinio koordinavimo. Daugeliu atveju protestai vyko net be tradiciškai režimams oponuojančių politinių grupių aktyvaus dalyvavimo?.

Svarbų vaidmenį arabų sukilimuose (ypač Egipto atveju) suvaidino socialiniai tinklai „Facebook“ ir „Twitter“. Jie turëjo įtakos sukilimų intensyvumui ir

\footnotetext{
Malik H., "Is It the Arab Spring?", USA: Johns Hopkins University, 3003 2011, , http://www.sais-jhu.edu/ bin/k/i/Is_It_The_Arab_Spring_30-3-11.pdf, 15042011.

${ }^{8}$ Joshi S., „Reflections on the Arab Revolutions: Order, Democracy and Western Policy“, The RUSI Journal, 156(2), April/May 2011, p. 64.

${ }^{9}$ Cheterian V., "The Arab Revolt: Roots and Perspectives", GCSP Policy Paper $n^{\circ} 11$, February 2011, http:// www.gcsp.ch/content/download/4739/45272/download, 20042011.
} 
plitimo regione greičiui. Tačiau „Facebook“ ir „Twitter“ ittakos arabų sukilimams nederètų pervertinti. Sukilimų metu ne mažiau svarbų vaidmenị atliko informacija, perduodama mobiliaisiais telefonais ${ }^{10}$ ir palydovinès televizijos, daugiausia - „Al Jazeera“ ir „Al Arabiya“, kanalais. Be to, naujausiomis technologijomis arabų sukilimų metu sèkmingai naudojosi ir autokratiniai režimai. Mobiliuosius telefonus ir „Facebook“ autokratiniai režimai sugebëjo išnaudoti kaip oponentų identifikavimo ir sekimo instrumentus.

Arabų sukilimų analize sunkiai įsivaizduojama be klausimo, kas iš tiesų yra arabų sukilèliai, pateikimo. Kas drịso sukilti prieš Vidurio Rytų valstybes dešimtmečiais valdančius diktatorius? Pasak pačių diktatorių, sukilèliai yra nusikaltèliai, fundamentalistai, ekstremistai ir teroristai. Remiantis arabų sukilimus analizuojančiais ekspertais, sukileliai yra jaunimas, bedarbiai, paprasti darbininkai, profsąjungų nariai, Vakarų liberalioms vertybėms prijaučiantys asmenys, viduriniosios klasès atstovai, menininkai, intelektualai, feministes, žemdirbiai ir su „Al-Qaeda“ susiję teroristai. Iš tiesų sukileliai yra marga publika. Pavyzdžiui, Libijos sukilèlių suformuotai Pereinamajai nacionalinei tarybai priklauso religiniai konservatoriai, liberalai ir socialdemokratines vertybes ginantys asmenys ${ }^{11}$. Kiekvienoje sukilusioje Vidurio Rytų valstybëje protestuotojų branduolį sudaranti grupé yra savita. Egipte tokia grupé yra naujausias technologijas įvaldęs jaunimas, Bahreine - sunitu valdymu nepatenkinti vietos šiitai, Sirijoje - alavitų valdymu nepatenkinti vietos sunitai. Mika Aaltola ir Timo Behras visus sukilelius apibendrintai apibūdina kaip žmones, išaugusius vargingomis sąlygomis, paveiktus radikalių religinių idëjų ir totalitarizmo ${ }^{12}$.

Vienu sakiniu galima sakyti, kad arabų sukilimus lèmé nesuskaitoma daugybė ilgalaikių ir trumpalaikių socialinių, ekonominių, politinių ir religinių veiksnių. İvairūs arabų sukilimus analizuojantys ekspertai nurodo įvairias sukilimų priežastis. Tarp gausybès sukilimus lèmusių ar paskatinusių priežasčių minimos: didëjanti ekonominè nelygybè, kartų kaita, globali finansinè ir ekonominè krizé, korupcija, efektyvaus valdymo nebuvimas, režimų nesugebëjimas patenkinti didëjančių gyventojų lūkesčių, politinès represijos, spartus gyventojų skaičiaus augimas, didelis nedarbas, žemi atlyginimai, spartus maisto produktų ir būtiniausių vartojimo prekių kainų kilimas, klimato kaita.

İdomu pažymèti, kad Vidurio Rytų regiono valstybèms būdingos problemos, kurios sudaro palankias sąlygas sukilimams prasiveržti, gerai žinomos palyginti seniai.

\footnotetext{
${ }^{10}$ Galimybę naudotis internetu turi mažiau nei ketvirtadalis egiptiečių. Tačiau mobiliuosius telefonus turi maždaug 80 proc. egiptiečių. Žr.: Sharekh A., „Reform and Rebirth in the Middle East“, Survival, 53(2), April-May 2011, p. 56-57.

${ }^{11}$ Genugten S., „Libya after Gadhafi“, Survival, 53(3), June-July 2011, p. 62.

${ }^{12}$ Aaltola M., Behr T., The Arab Uprising: Causes, Prospects and Implications, The Finish Institute of International Affairs Briefing Paper 76, March 2011, www.fiia.fi/assets/publications/bp76.pdf, 02052011.
} 
2002 m. paskelbtame Jungtinių Tautų vystymo programos dokumente teigiama, kad arabų valstybèse pastebimas skurdas, netolygus ekonominis augimas, vandens trūkumas, maisto stygius, neigiamos klimato kaitos pasekmés, lyčių lygybès principo nesilaikymas, neigiamas karinių konfliktų poveikis valstybių pažangai, politinès laisvès varžymai ${ }^{13}$. Dokumente pažymima, kad arabų šalyse reikia aktyviau siekti teisès viršenybès ir valdžių atskyrimo principų taikymo, aktyvesnio politinio dalyvavimo.

Kalbant apie arabų sukilimus apibendrintai, galima nurodyti bendras sukilimus Vidurio Rytuose lèmusias priežastis. Tai, kad bendrų priežasčiu būta, liudija greitas protestų išplitimas visame Vidurio Rytų regione. Visoms sukilimų apimtoms arabų valstybèms būdinga, kad: pirma, pagal amžiaus vidurkị jų gyventojai yra labai jauni (žr. 1 lentelę); antra, daugelis jaunų arabų valstybių gyventojų neturi darbo ir nemato jokių geresnio gyvenimo perspektyvų ${ }^{14}$. Aaltola ir Behras teigia, kad sukilimus Vidurio Rytuose $2011 \mathrm{~m}$. lëme trys priežastys, kurias jie vadina "deficitais“ - ekonominis, laisvių ir orumo ${ }^{15}$. Orumo deficitas šiuo atveju suprantamas kaip valdančiųju pagarbos valdomiesiems stygius ir garbès nedaranti arabų valstybių veikla tarptautineje politineje arenoje (omenyje turimas kai kurių arabų valstybių pataikavimas Vakarams). Emmanuelio Toddo teigimu, sukilimus lemę trys veiksniai yra visame regione pastebimas spartus raštingų žmonių (ypač moterų) skaičiaus didëjimas, mažejjantis gimstamumas ${ }^{16}$ ir dažnëjantis endogamijos praktikos atsisakymas ${ }^{17}$.

Žinoma, kiekvieną sukilimą galima analizuoti ir kaip atskirą atvejị su unikaliu sukilimą lemusių priežasčių deriniu. Tokią analizę galima pagrịsti tuo, kad vadinamasis arabų blokas iš tiesų nèra toks homogeniškas, kaip kartais atrodo. Arabų valstybès tarpusavyje skiriasi pagal įvairius kriterijus (žr. 1 lentelę). Vienos yra labai turtingos (Bahreinas, Saudo Arabija, Libija), o kitos - skurdžios (Jemenas). Vienose Vidurio Rytų regiono valstybèse piliečiai turi palyginti daug politinių teisių ir laisvių (Irakas, Marokas, Jordanija), o kitose - mažai (Saudo Arabija, Libija,

${ }^{13}$ Plačiau žr.: United Nations Development Programme, Arab Human Development Report 2002, New York: UNDP Regional Bureau for Arab States, 2002, http://www.arab-hdr.org/publications/other/ahdr/ahdr2002e. pdf, 14112010 .

${ }^{14}$ Siekiant spręsti jaunų žmonių nedarbo problemą, per artimiausią dešimtmetį arabų šalys turètų sukurti beveik 51 mln. naujų darbo vietų. Cheterian V., "The Arab Revolt: Roots and Perspectives”, GCSP Policy Paper $n^{\circ} 11$, February 2011, http:// www.gcsp.ch/content/download/4739/45272/download, 20042011.

${ }^{15}$ Aaltola M., Behr T., The Arab Uprising: Causes, Prospects and Implications, The Finish Institute of International Affairs Briefing Paper 76, March 2011, www.fiia.fi/assets/publications/bp76.pdf, 02052011.

${ }^{16} 1975$ m. vienai arabu valstybès moteriai vidutiniškai tekdavo 7,5 vaiko, o 2005 m. - 3,5. Leick R., "A Look at the Root Causes of the Arab Revolution: Rising Literacy and a Shrinking Birth Rate - Spiegel Interview with French social scientist Emmanuel Todd”, Spiegel Online International, 2005 2011, http:// www.spiegel.de/international/world/0,1518,763537,00.html, 22052011.

${ }^{17}$ Leick R., "A Look at the Root Causes of the Arab Revolution: Rising Literacy and a Shrinking Birth Rate - Spiegel Interview with French social scientist Emmanuel Todd”, Spiegel Online International, 2005 2011, http://www.spiegel.de/international/world/0,1518,763537,00.html, 22052011. 
Sirija). Vienose arabų valstybėse yra daugiau korupcijos (Irakas, Jemenas, Libija), o kitose - mažiau (Bahreinas, Jordanija).

1 lentelè. Kai kurių Vidurio Rytų regiono valstybių charakteristikos

\begin{tabular}{|l|c|c|c|c|c|}
\hline Valstybè & $\begin{array}{c}\text { Valstybès vieta } \\
\text { pagal } \\
\text { demokratijos } \\
\text { lygi šalyje* }\end{array}$ & $\begin{array}{c}\text { Bendrosios } \\
\text { nacionalinès } \\
\text { pajamos vie- } \\
\text { nam } \\
\text { gyventojui JAV } \\
\text { doleriais / GNI } \\
\text { per capita** }\end{array}$ & $\begin{array}{c}\text { Valstybès vieta } \\
\text { pagal korupci- } \\
\text { jos suvokimo } \\
\text { indeksą** }\end{array}$ & $\begin{array}{c}\text { Bedarbių pro- } \\
\text { centas }^{* * * *}\end{array}$ & $\begin{array}{c}\text { Vidutinis }_{\text {gyventojų }} \\
\text { amžius }^{* * * *}\end{array}$ \\
\hline Alžyras & 125 & 8120 & 105 & 10 & 27,6 \\
\hline Bahreinas & 122 & 24710 & 48 & 15 & 30,9 \\
\hline Egiptas & 138 & 6160 & 98 & 9 & 24,3 \\
\hline Irakas & 111 & 3350 & 175 & 15,3 & 20,9 \\
\hline Jemenas & 146 & 2350 & 146 & 35 & 18,1 \\
\hline Jordanija & 117 & 5810 & 50 & 12,5 & 22,1 \\
\hline Libija & 158 & 16740 & 146 & 30 & 24,5 \\
\hline Marokas & 116 & 4620 & 85 & 9,1 & 26,9 \\
\hline Saudo & 160 & 22540 & 50 & 10,8 & 25,3 \\
\hline Arabija & 152 & 5150 & 127 & 8,3 & 21,9 \\
\hline Sirija & 144 & 8130 & 59 & 13 & 30 \\
\hline Tunisas & & & & \\
\hline
\end{tabular}

Iš visų arabų sukilimams įtaką dariusių veiksnių vertètų išskirti klimato kaitą. Vidurio Rytų regionas yra ypač jautrus maisto kainoms, kurioms tiesioginę itaką daro klimato kaita, t.y. globalus klimato atšilimas. Vienam Vidurio Rytų regiono gyventojui importuojamo maisto tenka daugiau nei bet kurio kito pasaulio regiono ${ }^{18}$. Maisto produktų (ypač cukraus, pieno ir duonos) kainų augimas buvo viena pagrindinių priežasčių, $2011 \mathrm{~m}$. pradžioje išvedusių i gatves Alžyro ir Tuniso protestuotojus. Todèl Sarah Johnstone ir Jeffrey Mazo pagrịstai gali teigti, kad klimato kaita (globalus atšilimas) nesukèlè arabų pavasario, tačiau paskatino ankstesnę jo pradžią.

\footnotetext{
${ }^{18}$ Johnstone S., Mazo J., „Global Warming and the Arab Spring“, Survival, 53(2), April-May 2011, p. 13. "Kuo didesnis skaičius, tuo valstybè mažiau demokratiška. Šaltinis: The Economist Intelligence Unit, Democracy Index 2010, http://graphics.eiu.com/PDF/Democracy_Index_2010_web.pdf, 30082011.

* Šaltinis: The World Bank, GNI per capita, http://data.worldbank.org/indicator/NY.GNP.PCAP.PP.CD, 30 082011.

${ }^{* * *}$ Kuo didesnis skaičius, tuo didesne korupcija. Šaltinis: Transparency International, Corruption Perceptions Index 2010 Results, http://www.transparency.org/policy_research/surveys_indices/cpi/2010/results, 30082011. ${ }^{* * * *}$ Šaltinis: Central Intelligence Agency, The World Factbook, https://www.cia.gov/library/publications/theworld-factbook/, 30082011.

${ }_{* * * * *}^{*}$ Šaltinis: Central Intelligence Agency, The World Factbook, https://www.cia.gov/library/publications/theworld-factbook/, 30082011.
} 
Arabų sukilimai ir jų baigtis sunkiai prognozuojami. Kiekvienas sukilimas yra procesas, kuris pasižymi tam tikromis ypatybèmis. Arabų sukilimai - šiuo metu tebevykstantys procesai. Be to, svarbu prisiminti, kad sukilimuose, kaip procesuose, dalyvauja mažiausiai dvi pusès. Jų veiksmai, kurie kartais sunkiai suprantami ir paaiškinami, lemia galutinį sukilimų rezultatą. Tikrosios arabų sukilimų pasekmés gali pasimatyti tik po kelių dešimtmečių. Kol kas aišku tik tiek, kad Vidurio Rytuose vyksta strategiškai svarbios permainos. Jos keičia politinę ir geopolitinę situaciją visame regione.

Iš pirmo žvilgsnio arabų sukilimai primena XX a. demokratizacijos bangas Azijoje, Lotynų Amerikoje, Europoje ir Afrikoje. Daugelis arabų protestuotojų jauni, atstovaujantys viduriniajai klasei ir sugebantys naudotis naujausiomis technologijomis. Tačiau nederètų užbègti îvykiams už akių ir jau šiandien sakyti, kad arabų sukilimai į Vidurio Rytų regioną atneš daugiau demokratijos. Didelè dalis protestuotojų nèra Vakarų vertybių ir Vakarų sukurtos tarptautinès sistemos rémëjai.

Norint pasakyti daugiau apie Vidurio Rytų demokratizacijos perspektyvas, kiekvieno sukilimo Vidurio Rytuose atveju reiketų kelti klausimą - koks yra sukilèlių tikslas? Deja, dažnai ị ši klausimą labai sudetinga surasti atsakymą. I gatves Vidurio Rytų valstybèse išejo daug žmonių, jaučiančių skirtingas politines, ekonomines ir socialines nuoskaudas. Vieniems norisi daugiau demokratijos ir liberalesnés santvarkos, antriems - ekonominių reformų, tretiems - socialinių pokyčių, ketvirtiems - visų minètų dalykų ar tiesiog permainų. Kol kas sunku tiksliai pasakyti, ko iš tiesų nori sukilę Libijos arba Sirijos gyventojai. Ar jie nori demokratijos? Šiuo metu būtų labai rizikinga pateikti teigiamą atsakymą i ǐ ši klausimą.

Daugelyje arabų šalių, kuriose $2011 \mathrm{~m}$. pradžioje vyko masiniai protestai, buvę nedemokratiniai režimai tebeegzistuoja. Net Tuniso ir Egipto sukilèlių pergalès prieš diktatorius negarantuoja, kad šiose valstybèse bus daugiau demokratijos. Valstybès vadovo pakeitimas dar nereiškia gilios viso režimo transformacijos. Diktatorių nuvertimas tẻra pirmas žingsnis galimų didesnių politinių pokyčių link. Tunise ir Egipte šiuo metu svarbiausias politinio žaidimo dalyvis - kariuomenè, o politinę galią igiję kariškiai retai būna dideli liberalai ir demokratinès santvarkos šalininkai. Pažymètina, kad po Mubarako nuvertimo Egipto kariuomene vykdè savavališkus areštus ir kankino suimtuosius ${ }^{19} .2011 \mathrm{~m}$. kovo pabaigoje kariuomene Egipte uždraudè rengti bet kokias demonstracijas.

Po sukilimų demokratijos lygis Vidurio Rytuose gali net sumažeti. Persijos illankos šalių bendradarbiavimo tarybos valstybès narès (Bahreinas, JAE, Kataras, Kuveitas, Omanas, Saudo Arabija) jau dabar siekia griežtesnès savo visuomenių kontrolès. Šių valstybių didžiuosiuose miestuose montuojamos naujos vaizdo

\footnotetext{
${ }^{19}$ Joshi S., „Reflections on the Arab Revolutions: Order, Democracy and Western Policy“, The RUSI Journal, 156(2), April/May 2011, p. 64
} 
stebëjimo kameros, žmonès raginami pranešti policijai apie kiekvieną valdžią kritikuojantį asmenį ${ }^{20}$. Daugelis Vidurio Rytų valstybių rodo didelį norą griežčiau kontroliuoti interneto vartotojus ir socialinių tinklų veiklą.

Žvelgiant į ateitị ir vertinant tiketiną arabų sukilimų baigtí, galima išskirti mažiausiai tris scenarijus. Vienas iš jų - Tianmenio aikštès tragedija - žiaurus susidorojimas su permainų siekiančiais demonstrantais. Susidorojimo su protestuotojais kelią pasirinko Bahreino, Libijos, Sirijos ir iš dalies Jemeno vadovai. Šis scenarijus gali baigtis pilietiniu karu, o pastarasis - diktatoriams palankaus status quo atkūrimu arba sukilèlių pergale ir rimtais politinès sistemos pokyčiais. Antrasis scenarijus - paviršinès kosmetinès reformos. Pagal ši scenarijų autokratiniai režimai igyvendina nedideles politines reformas, tačiau nesiima spręsti esminių problemų. Toks scenarijus atitinka Alžyro, Jordanijos, Maroko, Omano ir Saudo Arabijos valdančiujjų elgesį. Trečiasis scenarijus - Turkijos kelias. Daugelis ekspertų pažymi, kad protestuotojai Vidurio Rytuose palankiai vertina Turkijos politinę sistemą, kurioje yra demokratijos bruožų, bet didele politinè galia svarbiausiais strateginiais klausimais sutelkta generolų rankose. Ekspertų vertinimu, labiausiai tikètina, kad Turkijos kelio scenarijų bus bandoma igyvendinti Tunise ir Egipte.

Taigi, Tunise prasidęję arabų sukilimai turi panašumų, tačiau jiems būdingi ir svarbūs skirtumai. Tolesnè arabų sukilimų eiga sunkiai prognozuojama. Svarbiausios jų pasekmès Vidurio Rytų regionui gali paaiškèti tik po kelių dešimtmečių. Sukilelių pergalès Tunise ir Egipte negarantuoja, kad šiose šalyse îvyks esminiai politinių sistemų pokyčiai ir bus daugiau demokratijos. Arabų sukilimų metu iškilusios naujos politinès jẻgos pačios gali būti nuverstos naujos sukilimų bangos, jei nesugebès sèkmingai spręsti įsisenëjusių politinių, ekonominių ir socialinių problemų.

\section{Arabų sukilimų poveikis Vakarų saugumo interesams}

Šị skyrių verta pradèti nuo trumpos Vakarų (NATO ir ES valstybių) interesų Vidurio Rytų regione apžvalgos. Remiantis Samueliu P. Huntingtonu, esminis Vakarų interesas, kuris taip pat aktualus kalbant ir apie Vidurio Rytu regioną, yra Vakarų civilizacijos dominavimo pasaulyje išsaugojimas ${ }^{21}$. Siekdami šio tikslo, Vakarai turi kontroliuoti situaciją kituose regionuose taip, kad jie nekeltų grésmés Vakarų saugumui. Paprastai tariant, nè vienas Vakarų valstybès politinis lyderis

\footnotetext{
${ }^{20}$ Smoltczyk A., Windfuhr V., "Arab Spring Stalls", Spiegel Online International, 1805 2011, http://www. spiegel.de/international/world/0,1518,762861,00.html, 19052011.

${ }^{21}$ Huntington S. P., „The Clash of Civilizations?“, Foreign Affairs, 72(3), 1993, p. 40.
} 
nenoretų matyti kažko panašaus į Vienos apsiaustį, kurią XVI a. buvo surengusi Osmanų imperijos kariuomenè.

Žinoma, Huntingtono civilizacijų susidūrimo teoriją reikia vertinti kritiškai. Arabų sukilimų eiga ir pobūdis, remiantis Huntingtono teorija, sunkiai paaiškinami. Kita vertus, didžiųjų Vakarų valstybių siekis kontroliuoti politinius įvykius ir procesus Vidurio Rytuose yra „vieša paslaptis“. Remiantis Fredu Halliday, 1942 m. Didžioji Britanija priverte atsistatydinti Egipto premjerą Ali Mahirą, $1949 \mathrm{~m}$. CŽV prisidëjo prie karinių perversmų Sirijoje organizavimo, 1953 m. amerikiečių ir britų slaptosios tarnybos organizavo Irano premjero Mohammado Mosaddegho nuvertimą, 1956 m. britų ir prancūzų karinès pajegos kartu su Izraeliu dalyvavo karineje operacijoje prieš Egiptą 22 . Be to, vertetų prisiminti istoriją ir faktą, kad nuo Osmanų imperijos žlugimo iki Antrojo pasaulinio karo situaciją Vidurio Rytuose iš esmés visiškai kontroliavo didžiosios Europos valstybės.

Vakarų saugumas su Vidurio Rytais glaudžiai susijęs dèl įvairių priežasčių. Viena jų - geografinis Vidurio Rytų regiono artumas Vakarams. Vakarų civilizacijai priklausančios Pietų Europos valstybès turi sienas su Vidurio Rytų regiono valstybèmis. Vakarai Vidurio Rytuose nuo seno turi įvairių ekonominių interesų. Vidurio Rytai yra Vakarams svarbus energetinių išteklių šaltinis. Nuo šio regiono naftos buvo ir yra priklausoma Vakarų ekonomine bei komercine gerove ${ }^{23}$. Turtingos Vidurio Rytų valstybès po Antrojo pasaulinio karo yra vakariečių geidžiamos kaip jų pagamintos ginkluotés pirkejos. Vidurio Rytų regionas Vakarams svarbus dèl didelio iš šio regiono ị Vakarus (pirmiausia - ES valstybes) atvykstančio emigrantu srauto. Pastarąji dešimtmetị Vidurio Rytų regionas Vakarams ypač svarbus dèl vadinamojo „karo prieš terorą“. Šis regionas yra įvairių antivakarietiškų religinių teroristinių grupių veikimo centras. Vidurio Rytų regionas Vakarus domina kaip vakarietiškų politinių ir ekonominių vertybių skleidimo zona ${ }^{24}$. Vienas svarbiausių JAV, galingiausios Vakarų valstybés, interesų Vidurio Rytuose - Izraelio saugumo ir ekonominès gerovés užtikrinimas ${ }^{25}$. Verta prisiminti, kad šaltojo karo metais Vidurio Rytai buvo geopolitiniu požiūriu ypač svarbi Vakarų ir Sovietų Sąjungos kovos dèl įtakos arena.

XX a. antroje pusëje ir XXI a. pradžioje Vakarų interesus Vidurio Rytuose dažniausiai gyne arba Vakarams naudingą jègų balansą palaikè Izraelis, regione ir

\footnotetext{
${ }^{22}$ Halliday F., The Middle East in International Relations: Power, Politics and Ideology, US: Cambridge University Press, 2005, p. 70.

${ }^{23}$ Milton-Edwards B., Hinchcliffe P., Conflicts in the Middle East since 1945, Third edition, UK: Routledge, 2008 , p. 38.

${ }^{24}$ Huntington S. P., „The Clash of Civilizations?“, Foreign Affairs, 72(3), 1993, p. 40.

${ }^{25}$ Milton-Edwards B., Hinchcliffe P., Conflicts in the Middle East since 1945, Third edition, UK: Routledge, 2008, p. 38-39.
} 
jo prieigose dislokuoti amerikiečių kariai bei autokratiniai musulmoniškų valstybių vadovai. Vakarams lojalią užsienio politiką vykdantys diktatoriai buvo naudingi ir reikalingi. Veikdami per juos Vakarai buvo mažiau pastebimi. Vietos diktatoriais sumaniai manipuliuojančius Vakarus buvo sunku kaltinti del tiesioginio kišimosi i Vidurio Rytų valstybių reikalus. Todèl natūralu, kad iki arabų sukilimų galingiausių Vakarų valstybių vadovai ilgai nemąstydavo ir, siekdami sau palankaus stabilumo, regione glaudžiai bendradarbiaudavo su autokratinių režimų vadovais ${ }^{26}$. Remiantis Shashanku Joshi, igyvendindami savo interesus Vidurio Rytuose, Vakarai nuolat sprendžia trilemą ${ }^{27}$. Kas jiems svarbiau? Stabilumas, demokratija ar Vakarams lojali arabų valstybių užsienio politika? Joshi pripažįsta, kad iki arabų sukilimų Vakarai prioritetą dažniausiai teike stabilumui ir provakarietiškai arabų valstybių užsienio politikai, o ne demokratijai.

$\mathrm{XX}$ a. demokratijos sklaida Vidurio Rytuose Vakarų valstybiu iš esmès nedomino. Remiantis Rashidu Khalidi, Vakarai nebuvo suinteresuoti demokratijos sklaida Vidurio Rytuose. Priešingai - demokratijos apraiškas Vidurio Rytuose Vakarai dažnai sąmoningai slopino ${ }^{28}$. Jiems buvo palankiau tvarkyti reikalus su lengvai manipuliuojamais ir prognozuojamais autokratiniais vadovais nei daugiau demokratijos siekiančiais lyderiais, kurie turi atsižvelgti į visuomenès nuomonę.

Vakarų politiką Vidurio Rytuose planuojančius strategus dažniausiai mažai jaudino šio regiono valstybių vidaus politika. Vardan stabilumo Vidurio Rytuose buvo galima "nepastebėti“ šio regiono autokratinių režimų trūkumų - valdančiuosiuose sluoksniuose klestinčios korupcijos, žmogaus ir piliečio teisių varžymo, vietinių saugumo ir žvalgybos tarnybų siautejimo. Jei Vakarų valstybèse kažkas dèl bendradarbiavimo su diktatoriais imdavo kritikuoti vietos politinius lyderius, tai jie visada rasdavo pasiteisinimą - bendradarbiavimas su Vidurio Rytų valstybių diktatoriais yra būtinas, nes tik jis garantuoja nenutrūkstamą naftos tekëjimą i Vakarus ir užkerta kelią radikalių islamistų ịsigalëjimuii ${ }^{29}$.

Vakarų interesai ir dešimtmečius trukęs bendradarbiavimas su Vidurio Rytų autokratiniais politiniais lyderiais paaiškina, kodèl daugelis Vakarų valstybių vadovų tik prasidejjus arabų sukilimams atrode pasimetę. Daugelis didžiųjų Vakarų valstybių lyderių ilgai delsè išsakyti savo paramą net tiems arabų sukilèliams, kurie atvirai skelbè savo šalyse siekiantys daugiau Vakarų tipo demokratijos. Vakarų strategams

\footnotetext{
${ }^{26}$ Cheterian V., "The Arab Revolt: Roots and Perspectives", GCSP Policy Paper n¹1, February 2011, http:// www.gcsp.ch/content/download/4739/45272/download, 20042011.

${ }^{27}$ Joshi S., „Reflections on the Arab Revolutions: Order, Democracy and Western Policy“, The RUSI Journal, 156(2), April/May 2011, p. 60.

${ }^{28}$ Rashid Khalidi, „The Arab Spring“, The Nation, 292(12), 2103 2011, p. 8.

${ }^{29}$ Joshi S., „Reflections on the Arab Revolutions: Order, Democracy and Western Policy“, The RUSI Journal, 156(2), April/May 2011, p. 62.
} 
reikèjo laiko pergalvoti ilgametę politiką Vidurio Rytų valstybių atžvilgiu. Kaip bus su Vakarų interesų užtikrinimu, jei lengvai manipuliuojamus ir prognozuojamus Vidurio Rytų diktatorius pakeis neaiškūs nauji politiniai žaidejjai?

Taigi, tik prasidejus sukilimams oficialūs asmenys Vašingtone, Londone, Paryžiuje ir Briuselyje tylëjo. Jų tylëjimą galima suprasti. Vidurio Rytų diktatoriai savo sukauptus turtus laikè Vakarų valstybèse esančiuose bankuose. Prancūzijos politiniai lyderiai palaike artimus ryšius su Tuniso autokratinio lyderio aplinkos žmonèmis. 2010 m. lapkritị-2011 m. vasarị Prancūzijos užsienio ir Europos reikalų ministrès pareigas ëjusi Michele Alliot-Marie skraidè Ben Ali aplinkos žmonèms priklausančiais privačiais lektuvais. Tik prasidëjus neramumams Tunise ji Ben Ali siūlè kovojant su protestuotojais pasinaudoti Prancūzijos saugumo pajegų atstovų pagalba ${ }^{30}$. Prancūzijos premjeras Francois Fillonas naudojosi Egipto lyderio Mubarako svetingumu ${ }^{31}$. Iki arabų sukilimų Prancūzija pelningai pardavinëjo ginkluotę Gaddafio valdomai Libijai.

Didžioji Britanija savo ginkluotę pardavinëjo Persijos įlankos autokratiniams režimams. Britų gaminamą ginkluotę premjeras Davidas Cameronas Persijos įlankos valstybių autokratiniams vadovams siūle įsigyti ir $2011 \mathrm{~m}$. vasarị vykusių oficialių vizitu metu ${ }^{32}$. JAV su Mubarako režimu dešimtmečius glaudžiai bendradarbiavo ivvairiais politiniais, kariniais ir ekonominiais klausimais. Kiekvienais metais Mubarako valdomam Egiptui JAV skirdavo karinès pagalbos už maždaug 1,5 mlrd. dolerių. Likus dviem savaitems iki priverstinio Mubarako atsistatydinimo JAV viceprezidentas Joe Bidenas Egipto vadovą vadino Amerikos sąjungininku ir atsakingu politiniu lyderiu. Jis siūle Mubarako daugiau nebevadinti diktatoriumi ${ }^{33}$.

JAV ir Egipto bendradarbiavimas saugumo klausimais tapo ypač intensyvus po 2001 m. rugsëjo 11 d. teroristinių išpuolių Niujorke ir Vašingtone. Egipto saugumo tarnybos daug padëjo amerikiečiams sulaikant ir tardant įtariamus teroristus ${ }^{34}$. Egiptas buvo svarbi JAV užsienio politikos interesams tarnaujančios aljansų sistemos Vidurio Rytuose dalis. Ši valstybè užemè strategiškai svarbią vietą JAV suburtame Iranui priešiškų Vidurio Rytų regiono valstybių bloke. Mubarako valdomas Egiptas palaikè gerus santykius su JAV protežè (pranc. protégé) regione -

\footnotetext{
${ }^{30}$ Joshi S., „Reflections on the Arab Revolutions: Order, Democracy and Western Policy“, The RUSI Journal, 156(2), April/May 2011, p. 61.

${ }^{31}$ Cheterian V., "The Arab Revolt: Roots and Perspectives", GCSP Policy Paper n ${ }^{\circ} 11$, February 2011, http:// www.gcsp.ch/content/download/4739/45272/download, 20042011.

${ }^{32}$ Joshi S., „Reflections on the Arab Revolutions: Order, Democracy and Western Policy“, The RUSI Journal, 156(2), April/May 2011, p. 61.

${ }^{33}$ The Christian Science Monitor, "Joe Biden says Egypt's Mubarak no dictator, he shouldn't step down...”, USA: The Christian Science Monitor, 2701 2011, http://www.csmonitor.com/World/Backchannels/2011/0127/Joe-Biden-says-Egypt-s-Mubarak-no-dictator-he-shouldn-t-step-down, 05062011.

${ }^{34}$ Cheterian V., "The Arab Revolt: Roots and Perspectives", GCSP Policy Paper ${ }^{\circ} 11$, February 2011, http:// www.gcsp.ch/content/download/4739/45272/download, 20042011.
} 
Izraeliu. Todèl kiti JAV sąjungininkai Vidurio Rytuose akylai stebejo Vašingtono elgesį su Mubaraku sukilimo Egipte metu. Skubota ir gerai neapgalvota Vašingtono reakcija ị arabų sukilimus galëjo lengvai sugriauti visą proamerikietišką aljansų sistemą Vidurio Rytuose, kurią JAV sunkiai kūre dešimtmečiais ${ }^{35}$.

JAV, galingiausios Vakarų valstybès, reakcija ị arabų sukilimus virto vadinamąja Obamos doktrina. Vertètų pažymėti, kad šios doktrinos paieškos pradètos dar gerokai prieš arabų sukilimų pradžią. Doktrinos ištakomis galima laikyti Obamos prezidentinę rinkimų kampaniją, kuri oficialiai pradèta $2007 \mathrm{~m}$. vasarị. Pagrindus šiai doktrinai padëjo 2009 m. birželio 4 d. prezidento Obamos pasakyta kalba Kaire, skirta JAV santykių su musulmonų bendruomenėmis peržiūrejjimui. Iš esmès Obamos doktrina yra bandymas santykiuose su musulmonais atsiriboti nuo buvusio prezidento George'o W. Busho užsienio politikos doktrinos. Buvęs JAV prezidentas demokratijos sklaidą Vidurio Rytuose buvo iš esmès sutapatinęs su nedemokratinių režimų keitimo politika, kuri rèmési Amerikos karine galia. Pažymètina, kad Busho doktrina niekada nebuvo labai mégiama arabų pasaulyje.

Obama, siekdamas atsiriboti nuo Busho palikimo, arabų sukilimų kontekste kiek įmanydamas vengè naudoti frazę „režimo keitimas“. $2011 \mathrm{~m}$. gegužès $9 \mathrm{~d}$. savo kalboje Obama nurode šiuos principus, kuriais JAV vadovausis dèl arabu sukilimų: pirma, JAV nepritars prievartos naudojimui ir represijoms prieš Vidurio Rytų regiono gyventojus; antra, JAV rems universalias teises (pavyzdžiui, žodžio laisvès, taikių susirinkimų, tikëjimo laisvès, lyčių lygybès, teisès viršenybès, lyderių pasirinkimo laisvès); trečia, JAV rems politines ir ekonomines reformas, kurios gali patenkinti teisetus paprastų regiono gyventojų lūkesčius ${ }^{36}$. JAV elgesys arabų sukilimų metu parode, kad Obamos administracija yra linkusi pirmiausia gauti tarptautinị pritarimą ir tik tuomet imtis karinių priemonių taikymo. Pasak Bruce’o Joneso, Obamos administracija daugiausia demesio skiria veikimui diplomatiniais kanalais ir kompromisu su oponentais paieškoms ${ }^{37}$. Anot Marco Lyncho, JAV elgesys Egipto sukilimo atveju sukūrè elgesio šabloną, kuriuo Vašingtonas galès vadovautis visame Vidurio Rytų regione $e^{38}$.

Vis dèlto savotišku Obamos doktrinos išbandymu tapęs sukilimas Bahreine parodé, kad kalbos lieka kalbomis, o interesai - interesais. Bahreino režimas, padedamas Saudo Arabijos ir JAE, jega susidorojo su vietos sukileliais. Tuo metu Bahreine dislokuoti JAV karinio jūrų laivyno penktosios flotilès atstovai liko abe-

35 Lynch M., „America and Egypt After the Uprisings“, Survival, 53(2), April-May 2011, p. 35.

${ }^{36}$ Obama B., "A Moment of Opportunity", Washington: The White House, 1905 2011. http://www.

whitehouse.gov/the-press-office/2011/05/19/remarks-president-barack-obama-prepared-delivery-momentopportunity, 25052011.

${ }^{37}$ Jones B. D., „Libya and the Responsibilities of Power“, Survival, 53(3), June-July 2011, p. 58.

${ }^{38}$ Lynch M., „America and Egypt after the Uprisings“, Survival, 53(2), April-May 2011, p. 32. 
jingi šio susidorojimo stebėtojai ${ }^{39}$. Panašiai abejingai Vašingtonas žiūri ị Sirijos vadovo organizuojamą susidorojimą su vietos sukilèliais. Todèl Habibas Malikas daro išvadą, kad kol kas Al-Assado režimas JAV mielesnis, nei galimas sunitų dominuojamas Sirijos politinis režimas arba visiškas chaosas ${ }^{40}$.

Vienu ryškiausių Vakarų paramos arabų sukileliams atveju būtų galima laikyti karinị Vakarų valstybių įsikišimą i sukilimą Libijoje. Vakarų valstybių (JAV, Prancūzijos ir Didžiosios Britanijos) iniciatyva JT Saugumo Taryba $2011 \mathrm{~m}$. kovo 17 d. prièmè rezoliuciją numeris 1973. Ši rezoliucija nurodè Gaddafiui nedelsiant nutraukti sukilèlių puolimą, numate ginklų embargo ịvedimą, neskraidymo zonos virš Libijos sukūrimą, tarptautinei bendrijai suteike teisę naudoti visas būtinas priemones Libijos civilių gyventoju apsaugai užtikrinti ${ }^{41}$. Kovo 19 d. JAV, Prancūzija ir Didžioji Britanija pradëjo karines atakas prieš sukilelius puolančias Gaddafiui lojalias karines pajegas. Kovo 27 d. karinei misijai, kuria siekiama rezoliucijos 1973 igyvendinimo, pradejo vadovauti $\mathrm{NATO}^{42}$.

Karinè misija Libijoje - trečia didelè pastarujų metų Vakarų karinè operacija musulmoniškoje valstybëje. Tiesa, JAV visomis išgalemis siekia išvengti operacijos Libijoje lyginimo su amerikiečių misijomis Afganistane ir Irake. Vašingtonas tik gavęs progą vadovavimą karinei operacijai Libijoje perdave NATO, nors iš pradžiu apskritai norejo vadovavimą šiai misijai atiduoti kuriai nors iš didžiųju ES valstybių ${ }^{43}$. Pažymėtina, kad didžiųjų Vakarų valstybių lyderiai, remdamiesi Afganistano ir Irako pamokomis, iškart atmete sausumos karinès intervencijos i Libiją idejją. Ittakingos NATO nares, Vokietija ir Turkija, apskritai pradžioje turëjo labai daug abejonių dèl bet kokio Aljanso karinio ịsitraukimo ị sukilimą Libijoje reikalingumo.

Vakarų įsitraukimas į Libijos sukilimą vertintinas nevienareikšmiškai. Jis tarsi liudija, kad Vakarai palaiko permainų trokštančius Libijos sukilèlius ${ }^{44}$. Kita vertus, Vakarai kartais atrodo sutrikę dèl savo sprendimo karine jega paremti Libijos protestuotojus. Iš tiesų ši operacija Vakarams kelia ne itin malonius prisiminus apie demokratijos kūrimo eksperimentus Afganistane ir Irake. Pasak Saskia van Ge-

\footnotetext{
${ }^{39}$ Smoltczyk A., Windfuhr V., "Arab Spring Stalls”, Spiegel Online International, 1805 2011, http://www. spiegel.de/international/world/0,1518,762861,00.html, 19052011.

${ }^{40}$ Malik H., "Is It the Arab Spring?”, USA: Johns Hopkins University, 3003 2011, http://www.sais-jhu.edu/ bin/k/i/Is_It_The_Arab_Spring_30-3-11.pdf, 15042011.

${ }^{41}$ United Nations Security Council, "Resolution 1973 (2011)", New York: United Nations, 1703 2011, http://daccess-dds-ny.un.org/doc/UNDOC/GEN/N11/268/39/PDF/N1126839.pdf?OpenElement, 2203 2011.

${ }^{42}$ Plačiau žr.: NATO, "NATO and Libya - Operation Unified Protector", Belgium: NATO Headquarters, 04 05 2011, http://www.nato.int/cps/en/natolive/topics_71652.htm?, 14072011.

${ }^{43}$ Anand Menon, „European Defence Policy from Lisbon to Libya“, Survival, 53(3), June-July 2011, p. 75.

${ }^{44}$ Verta pažymèti, kad šiuo atveju Vakarai nèra vieningi. Pavyzdžiui, Vokietija nebuvo Vakarų karinio dalyvavimo Libijos sukilime šalininkè. Balsuodama JT Saugumo Taryboje ji neparèmè rezoliucijos 1973 prièmimo.
} 
nugten, Libijos tauta ir valstybè statoma ant smèlio ${ }^{45}$. Panašiai ir ne itin sèkmingai Vakarai ant smëlio jau kūre Afganistano ir Irako tautas bei valstybes.

Neaišku, kokiu keliu eitų Libija, jei pilietiniame kare vis dèlto laimètų sukilèliai. İtakingas NATO generolas James Stavridis yra viešai pareiškęs, kad Libijos sukilëlių gretose šmèkščioja su „Al-Qaeda“ ir „Hezbollah“ susiję asmenys ${ }^{46}$. Su Libijos sukilimu susiję Vakarams aktualūs, bet kol kas neatsakyti klausimai, kurie svarbūs ir kitų arabų sukilimų atvejais, gali būti viena priežasčių, kodèl Vakarai vengia tiesioginio karinio kišimosi į kitus arabų sukilimus.

Beveik visi arabų sukilimus analizuojantys ekspertai pastebi, kad Vakaru valstybių vaidmuo arabų sukilimuose labai svarbus. Tačiau Vakarų galimybès nulemti vienokią ar kitokią sukilimų baigti yra ribotos. Vakarai jaučia, kad negali kontroliuoti demokratijos pletros Vidurio Rytuose proceso ir todèl bijo kaip nors jị skatinti ${ }^{47}$.

Koks bus arabų sukilimų poveikis Vakarų saugumo interesams Vidurio Rytuose? Tikètina, kad svarbiausi Vakarų saugumo interesai nesikeis. Greičiausiai, Vakarų interesus Vidurio Rytuose toliau mégins igyvendinti vakariečiai strategai, kurie yra realiosios politikos principų šalininkai. Kas tuomet keisis? Vakarams bus sunkiau igyvendinti savo interesus. Paprasti Vakarų piliečiai po arabų sukilimų gali atkakliau reikalauti savo politinių lyderių nebendradarbiauti su autokratinių Vidurio Rytų režimų atstovais. Po sukilimų paprastų Vakarų valstybių gyventojų požiūris į arabus turètų gerokai pasikeisti. Remiantis Joshi, didžiausias arabų sukilimų poveikis Vakarams būtent ir bus paprastų vakariečių požiūrio i̇ arabus pasikeitimas $^{48}$. Jei anksčiau daugelis vakariečių arabus laikẻ globalizacijos proceso nuošaleje likusiais barzdotais radikalais, tai dabar arabų įvaizdis Vakarų visuomenèse turètų būti kitoks. Arabų sukilèliai paprastiems Vakarų gyventojams parodè, kad daugelis jaunų arabų moka gerai naudotis globalizacijos amžiaus technologijomis ir nera Irano tipo teokratinio valdymo šalininkai.

Vakarams Vidurio Rytuose bus sunkiau igyvendinti savo interesus ir dèl pačių arabų požiūrio ị bendradarbiavimą su Vakarais pasikeitimo. Arabų valstybès, kur sukilèliams pavyko pasiekti didesnių ar mažesnių laimëjimų, gali mažiau paisyti didžiųjų Vakarų valstybių norų ir vykdyti savarankiškesnę užsienio politiką. Akivaizdu, kad daugelis naujų ir senų Vidurio Rytų valstybių politinių lyderių

\footnotetext{
${ }^{45}$ Genugten S., „Libya after Gadhafi“, Survival, 53(3), June-July 2011, p. 72.

${ }^{46} \mathrm{CNN}$, "Flickers' of al Qaeda in Libyan opposition, U.S. NATO leader says", US: Turner Broadcasting System Inc., 2903 2011, http://articles.cnn.com/2011-03-29/us/libya.opposition.analysis_1_james-stavridismoammar-gadhafi-al-qaeda-or-one?_s=PM:US, 07072011.

${ }^{47}$ Joshi S., „Reflections on the Arab Revolutions: Order, Democracy and Western Policy“, The RUSI Journal, 156(2), April/May 2011, p. 62.

${ }^{48}$ Joshi S., „Reflections on the Arab Revolutions: Order, Democracy and Western Policy“, The RUSI Journal, 156(2), April/May 2011, p. 61.
} 
atkreips dèmesị ị tai, kad viena Mubarako režimo žlugimą lèmusių priežasčiu Egipto gyventojų nepasitenkinimas jo vykdyta užsienio politika. Egipto sukilèliai aiškiai leido suprasti, kad jiems nepatinka, kai jų šalis tarptautinëje politikoje atlieka amerikiečiams paklusnaus šunelio vaidmenį ${ }^{49}$. Sukilę arabai nepasitiki Vakarais, kurie dešimtmečiais rèmè autokratinius arabų valstybių lyderius ir rūpinosi tik savo interesais ${ }^{50}$. Todèl arabų sukilimai gali reikšti Vakarų hegemonijos Vidurio Rytuose pabaigą ${ }^{51}$. Arabu sukilimai gali prisideti prie labiau decentralizuoto ir tikrai daugiapolio pasaulio atsiradimo.

Tikètina, kad po arabų sukilimų Egipto ir Vakarų sajungininko Izraelio bendradarbiavimas politineje, ekonominëje ir karinëje srityse susilpnès, nors dvišalè taikos sutartis neturètų būti sulaužyta. Vidurio Rytų valstybès gali Vakarams aštriau kelti Izraelio ir palestiniečiu konflikto sureguliavimo klausimą. Apskritai šio konflikto sprendimas būtų naudingas tiek arabams, tiek Vakarų valstybèms. $2002 \mathrm{~m}$. paskelbtame Jungtinių Tautų vystymo programos dokumente pažymima, kad Izraelio okupuotos palestiniečių teritorijos yra viena pagrindinių kliūčių viso regiono saugumui, ekonominiam ir socialiniam vystymuisi ${ }^{52}$.

Po arabų sukilimų Vakarams bus sunkiau bendradarbiauti su Vidurio Rytu valstybėmis kovojant prieš terorizmą. Vakarų ir arabų valstybių bendradarbiavimas kovojant su terorizmu niekada nebuvo tobulas. Tačiau nuo $2001 \mathrm{~m}$. pabaigos bendradarbiavimas kontrterorizmo srityje buvo viena prioritetinių ir geriausiai išplètotų Vakarų bei arabų valstybių bendradarbiavimo sričiu. Vakarų valstybès daug investavo ị arabų sukilelių nemégiamų vietinių saugumo ir žvalgybos tarnybų stiprinimą ${ }^{53}$. Amerikiečių FTB ir CŽV ilgai ir glaudžiai bendradarbiavo su Egipto SSIS (State Security Investigations Service/Valstybes saugumo tyrimų tarnyba) ${ }^{54}$. Tačiau kovo pradžioje su Mubarako valdymu ir įvairiais neteisètais veiksmais siejamos SSIS atstovybès virto Egipto protestuotojų atakų taikiniais. Tą pati méneși šalies vidaus reikalų ministerija buvo priversta uždaryti šią prastą reputaciją egiptiečių akyse turinčią tarnybą.

\footnotetext{
${ }^{49}$ Aaltola M., Behr T., The Arab Uprising: Causes, Prospects and Implications, The Finish Institute of International Affairs Briefing Paper 76, March 2011, www.fiia.fi/assets/publications/bp76.pdf, 02052011.

${ }^{50}$ Fakhro E., Hokayem E., „Waking the Arabs“, Survival, 53(2), April-May 2011, p. 24.

${ }^{51}$ Aaltola M., Behr T., The Arab Uprising: Causes, Prospects and Implications, The Finish Institute of International Affairs Briefing Paper 76, March 2011, www.fiia.fi/assets/publications/bp76.pdf, 02052011.

52 United Nations Development Programme, Arab Human Development Report 2002, New York: UNDP

Regional Bureau for Arab States, 2002, http://www.arab-hdr.org/publications/other/ahdr/ahdr2002e.pdf, 14 112010.

${ }^{53}$ Fakhro E., Hokayem E., „Waking the Arabs“, Survival, 53(2), April-May 2011, p. 27.

${ }^{54}$ McGregor A., "Egypt's Internal Security Service Collapses in a Storm of Charges and Revelations",

Terrorism Monitor, 9(14), 0704 2011, http://www.jamestown.org/single/?no_cache=1\&tx_ttnews[swords ]=8fd5893941d69d0be3f378576261ae3e\&tx_ttnews[any_of_the_words]=arab\%20revolts\&tx_ttnews[tt_ news] $=37766 \&$ tx_ttnews[backPid] =7\&cHash=431c2da3af2798288fbd84570ee52266, 07062011.
} 
Kita vertus, arabų sukilimai parode, kad „Al-Qaeda“, kurios taip bijo Vakarų valstybių gyventojai, yra palyginti mažai įtakos turinti radikalų grupe. „Al-Qaeda“ ir susijusių džihado kovotojų grupių atstovai arabų sukilimų metu pasirodẻ kaip marginalai, kurie neturi dideles įtakos arabų pasaulyje vykstančioms permainoms ${ }^{55}$. Paprasti civiliai Tunise ir Egipte per keletą savaičių pasieke tai, ko „Al-Qaeda“ ir susijusios grupés nesugebëjo pasiekti per maždaug du ginkluotos kovos dešimtmečius. Pasak Steveno Simono, arabų sukilimai reiškia strateginį karingųjų džihado kovotojų pralaimëjimą ${ }^{56}$.

Aišku, „Al-Qaeda “ ar susiję teroristai gali mėginti naujais išpuoliais paveikti situaciją Jemene, Libijoje ar kitose silpnose Vidurio Rytų valstybèse. Tačiau šiuo atveju verta pažymèti, kad „Al-Qaeda “ gebëjimas mobilizuoti ir į kovą ịtraukti mases visada buvo menkai išvystytas. Be to, džihado kovotojų teroristiniai išpuoliai prieš musulmonus civilius ir piešiamos apokaliptinès ateities pasaulio vizijos paprastiems arabams niekada nekelè didelio susižavejimo ${ }^{57}$.

Kai kurių radikalių grupių, kurios Vakaruose kartais priskiriamos teroristinėms, populiarumas arabų valstybèse po sukilimų gali padidèti. Daugelis protestuotojų 2011 m. pradžioje neslèpé savo simpatijų „Hezbollah“ lyderiui Hassanui Nasrallah ${ }^{58}$. Didele dalis sukilèlių atvirai reiške paramą palestiniečių "Hamas“. Po arabų sukilimų Vidurio Rytų valstybèse bent iš dalies gali būti legitimizuotas islamistų partijų ir judëjimų (pavyzdžiui, Musulmonų brolijos) dalyvavimas politikoje. Tačiau Vakarams islamistų legitimizavimo nereikia bijoti. Islamistai nèra džihadistai. Aktyvus islamistų dalyvavimas Vidurio Rytų valstybių politiniame gyvenime turètų tik padèti demokratijai įsitvirtinti šiame regione ${ }^{59}$.

Kalbant apie arabų sukilimų poveikį Vakarų interesams svarbu pažymėti, kad ilguoju periodu demokratijos įsitvirtinimas Vidurio Rytuose Vakarams galètų būti naudingas. Vakarų ir demokratiškesnių Vidurio Rytų regiono valstybių politinis dialogas, siekiant įvairių saugumo iššūkių sprendimo, galètų būti aiškesnis ir abiem pusèms naudingesnis. Problema ta, kad daugeliui Vidurio Rytų regiono valstybių kelias ị demokratiją gali būti labai ilgas arba apskritai neįveikiamas. Istorijoje galima rasti daug pavyzdžių, rodančių, kad demokratijos diegimas už tradicinių Vakarų pasaulio ribų gali atnešti prieštaringų rezultatų.

Taigi, arabų sukilimai Vakarų saugumo interesams bent jau trumpuoju periodu nežada nieko gero. Akivaizdu, kad Vakarų interesus atitinkančią politiką

\footnotetext{
${ }^{55}$ Fakhro E., Hokayem E., „Waking the Arabs“, Survival, 53(2), April-May 2011, p. 26.

${ }^{56}$ Shane S., "As Regimes Fall in Arab World, Al Qaeda Sees History Fly By", The New York Times, 2702

2011, http://www.nytimes.com/2011/02/28/world/middleeast/28qaeda.html, 04052011.

${ }^{57}$ Elham Fakhro, Emile Hokayem, „Waking the Arabs“, Survival, 53(2), April-May 2011, p. 26.

${ }^{58}$ Aaltola M., Behr T., The Arab Uprising: Causes, Prospects and Implications, The Finish Institute of International Affairs Briefing Paper 76, March 2011, www.fiia.fi/assets/publications/bp76.pdf, 02052011.

${ }^{59}$ Hamid Sh., „Arab Islamist Parties: Losing on Purpose?“, Journal of Democracy, 22(1), January 2011, p. 68-80.
} 
vykdę autokratiniai arabų lyderiai nebesugeba užtikrinti Vakarams reikalingo stabilumo. Antra vertus, kai kuriose arabų valstybèse valdžioje įsitvirtinantys nauji politiniai žaidejjai Vakarams nepažịstami ir dèl to sunkiai prognozuojami. Jų sugebëjimai sèkmingai spręsti įsisenëjusias arabų visuomenių politines, ekonomines ir socialines problemas kelia daug abejonių. Tai reiškia, kad nauji politiniai žaidejjai irgi gali būti nepajegūs sukurti Vakarams reikalingo stabilumo, jau nekalbant apie jų pajegumą sukurti Vakarų pavyzdžio, demokratinius režimus. Artimiausiu metu arabų sukilimai komplikuos Vakarų bendradarbiavimą su arabų valstybėmis kovojant prieš terorizmą. Europos valstybėms teks spręsti problemas, kurios kyla dèl padidejusio imigrantų srauto iš neramumų apimtų arabų šalių.

\section{Arabų sukilimai ir Lietuvos interesai}

Nuo 2004 m. Lietuva priklauso svarbiausioms Vakarų organizacijoms NATO ir ES. Lietuvai aktualios tos pačios saugumo problemos, kaip ir daugumai Vakarų valstybių. Lietuvos politineje darbotvarkëje palyginti dažnai minimi tokie klausimai kaip terorizmas, kibernetinès atakos, energetinis saugumas, klimato kaita. Neatsitiktinai apie tai kalbama ir naujausiame Lietuvos nacionalinio saugumo strategijos projekte ${ }^{60}$.

Globalizacijos proceso veikiama Lietuva negali atsiriboti nuo daugeliui pasaulio valstybių aktualių saugumo problemų. Remiantis Gediminu Vitkumi, globalizacijos amžiuje visų valstybių saugumas yra bendras ir nedalomas ị atskirus nacionalinius saugumus ${ }^{61}$. Nepaisant to, siekdama savo saugumo ir užsienio politikos tikslų realizavimo, Lietuva, kaip ir visos valstybes, turi savo prioritetus. Be to, Lietuva yra palyginti maža, silpna ir jauna valstybe ${ }^{62}$. Žmogiškieji ir materialiniai ištekliai, kuriuos Lietuva gali skirti savo saugumo ir užsienio politikai iggvendinti, yra palyginti menki.

Daugiausia démesio Lietuvos saugumo ir užsienio politikos formuotojai tradiciškai skiria kaimyninèms valstybèms - Rusijai, Baltarusijai, Lenkijai, Latvijai ir Estijai. Be šių valstybių palyginti didelis Vilniaus dẻmesys atitenka ị SSRS sudetị iejjusioms valstybėms. Iš jų galima išskirti tris - Gruziją, Moldovą ir Ukrainą. Aišku,

\footnotetext{
${ }^{60} \check{Z ̌ r}_{\text {.: }}$ Lietuvos Respublikos Seimas, „Nutarimas dèl Lietuvos Respublikos Seimo nutarimo „Dèl nacionalinio saugumo strategijos patvirtinimo" pakeitimo“ (nutarimo projektas), 0107 2011, http://www3.lrs.lt/pls/inter3/dokpaieska.showdoc_l?p_id=403085\&p_query=\&p_tr2=, 03082011.

${ }^{61}$ Vitkus G., „Integraciniai tarptautinio saugumo procesai versus jègų balansas“, Skaitiniai apie nacionalinị ir tarptautini sauguma, Vilnius: Atlanto sutarties Lietuvos bendrija, 2000, p. 17.

${ }^{62}$ Laurinavičius Č., Motieka E., Statkus N., Baltijos valstybiu geopolitikos bruožai: XX amžius, Vilnius: LII leidykla, 2005, p. 192.
} 
Lietuvai labai rūpi bendradarbiavimas su įtakingiausiomis Vakarų valstybèmis, iš kurių svarbiausia - JAV. Lietuvos narystę NATO kai kurie vietos saugumo ekspertai laiko išskirtinai JAV nuopelnu ${ }^{63}$. Anot jų, naryste ES Lietuvai garantuoja saugumą tik tol, kol pačios Sąungos saugumu rūpinasi JAV. Pažymètina, kad po Dalios Grybauskaites pergalès prezidento rinkimuose 2009 m. gegužę Lietuva daugiau demesio skiria santykiams su Briuseliu, Paryžiumi ir Berlynu, tačiau JAV Lietuvos saugumui dèl to netampa mažiau svarbios.

Svarbu pažymetti, kad Lietuva, nors ir disponuodama ribotais ištekliais, dalyvauja su nacionalinio saugumo ir užsienio politikos prioritetais menkai susijusiose, tačiau kitoms Vakarų valstybèms svarbiose karinèse misijose. Pavyzdžiui, ISAF misijoje Afganistane, NTM-I Irake (NATO Training Mission-Iraq) ir ES misijoje „Atalanta“ ${ }^{\text {64. }}$. Nuo 2005 m. Lietuva vadovauja Afganistano Goro provincijos atkūrimo grupei.

Vis dèlto galima teigti, kad Vidurio Rytų regionas Lietuvą domina kur kas mažiau nei iš tiesų artimi „Artimieji Rytai“ (Rusija ir Baltarusija) ir tokios valstybès kaip Gruzija, Moldova ar Ukraina. Pasak Vilniaus universiteto Tarptautinių santykių ir politikos mokslų instituto dėstytojo Egdūno Račiaus, Lietuva neturi tiesioginio priejimo prie Viduržemio jūros ir atitinkamų arabų valstybių. Todèl natūralu, kad Lietuva Vidurio Rytuose neturi ypatingų interesų $u^{65}$. Iš tiesu Lietuvos su Vidurio Rytų regiono valstybemis nesieja stiprūs istoriniai, politiniai ar ekonominiai ryšiai. Iš esmès Vidurio Rytai Lietuvą domina tiek, kiek įvykiai šiame regione gali paveikti JAV (NATO) ir ES saugumą.

Iš Vidurio Rytų arabų valstybių Lietuva savo diplomatinę atstovybę turi tik lietuvių turistų pamègtame Egipte. Teoriškai Lietuvos ambasada Egipte turètų kuruoti Lietuvos interesus Jordanijoje, Sirijoje, Libane, Kuveite, JAE, Saudo Arabijoje ir Katare. Tačiau praktiškai ambasada Kaire to daryti negali, nes joje, remiantis $2011 \mathrm{~m}$. rugpjūčio $5 \mathrm{~d}$. informacija, dirba tik du žmonès ${ }^{66}$. Palyginimui, tuo pačiu metu Moldovoje esančioje Lietuvos ambasadoje, kuri rūpinasi Lietuvos interesais tik šioje šalyje, dirba 3 žmonès.

\footnotetext{
${ }^{63}$ Laurinavičius Č., Motieka E., Statkus N., Baltijos valstybiu geopolitikos bruožai: XX amžius, Vilnius: LII leidykla, 2005, p. 192.

${ }^{64}$ Krašto apsaugos ministerija, „Kodèl ir kur dalyvaujame“, 2303 2011, http://www.kam.lt/lt/tarptautinis_ bendradarbiavimas/tarptautines_operacijos/kodel_dalyvaujame.html, 08082011.

${ }^{65}$ Balsas.lt, „E. Račius: pretekstas pulti Libiją buvo, tik klausimas, ar pakankamas?“, Vilnius: UAB "Balsas.lt”, 2303 2011, http://www.balsas.lt/naujiena/530873/e-racius-pretekstas-pulti-libija-buvo-tik-klausimas-ar-pakankamas-video-foto, 26072011.

${ }^{66}$ Užsienio reikalų ministerija, „LR Ambasada Egipto Arabų Respublikoje, Jordanijos Hašimitų Karalystei, Sirijos Arabų Respublikai,Libano Respublikai, Kuveito Valstybei, Jungtiniams Arabų Emyratams, Saudo Arabijos Karalystei ir Kataro Valstybei“, 0508 2011, http://www.urm.lt/popup2.php?tmpl_name=m_urm_ lt_embassy\&m_urm_country_id=57, 10082011.
} 
Lietuvos ir Vidurio Rytų valstybių prekybiniai ryšiai nèra išplètoti. Remiantis Lietuvos statistikos departamento $2011 \mathrm{~m}$. pirmoje puseje paskelbta informacija, bent jau pirmuose dviejuose didžiausių Lietuvos užsienio prekybos partnerių dešimtukuose nèra nè vienos Vidurio Rytu regiono valstybès ${ }^{67}$. Dvišalis Lietuvos ir Vidurio Rytų regiono valstybių karinis bendradarbiavimas praktiškai nevyksta.

Menki Lietuvos interesai Vidurio Rytuose ir labai silpni dvišaliai ryšiai su šio regiono valstybemis nesutrukdè šalies politiniams lyderiams išsakyti savo pozicijos arabų sukilimų klausimu. Lietuvos politinių lyderių reakciją i arabų sukilimus lèmé didelis arabų sukilimams rodomas dèmesys ivvairiuose tarptautiniuose politiniuose forumuose (pirmiausia - NATO ir ES) bei užsienio ir vietos žiniasklaidos susidomëjimas vadinamuoju arabų pavasariu. Lietuvos politinius lyderius išsakyti tam tikrą poziciją dèl arabų sukilimu galëjo paskatinti šalies pirmininkavimas ESBO ir Demokratijų bendrijai. Be to, nereikètų pamiršti, kad Lietuva turi arabų sukilimus primenančią patirti.

1988-1991 m. Lietuvoje, Latvijoje ir Estijoje vyko vadinamosios dainuojančiosios revoliucijos, kurių metu buvo siekiama totalitarinę politinę sistemą pakeisti liberalia demokratine. Galima sakyti, kad Lietuva turi net savo Bouazizį- 1972 m. gegužę Kaune susideginusį Romą Kalantą ${ }^{68}$. Tiesa, dainuojančiosios revoliucijos ir arabų sukilimai nèra tokie panašūs, kaip gali pasirodyti iš pirmo žvilgsnio. Pirma, arabų sukilimai neigijo tokio ryškaus ideologinio atspalvio kaip dainuojančiosios revoliucijos. Antra, Rytų Europoje komunizmo žlugimas buvo palyginti greitas ir visa apimantis, o daugelyje arabų šalių autokratiniai režimai, nepaisant masinių protestų bangos, vis dar gana sèkmingai priešinasi permainoms.

Lietuvos politiniai lyderiai pasisake arabų sukilimų klausimais, tačiau apskritai šiems sukilimams buvo skirta palyginti nedaug jų dèmesio. Dainuojančiosios revoliucijos patirti turinti Lietuva neskubejjo ypač džiaugtis galimomis demokratijos plètros Vidurio Rytuose perspektyvomis. Politologas Giedrius Česnakas teisus teigdamas, kad Lietuvos politiniai lyderiai neišnaudojo politiškai dèkingos situacijos, pirmininkavimo ESBO ir Demokratijų bendrijai teikiamų galimybių demokratijos plètrai Vidurio Rytuose skatinti ${ }^{69}$. Kita vertus, reikia pažymèti, kad pernelyg neskubèdami džiaugtis naujomis demokratijos plètros Vidurio Rytuose perspektyvomis Lietuvos politiniai lyderiai elgesi apdairiai. Kol kas niekas negali vienareikšmiškai pasakyti, kaip toliau Vidurio Rytuose klostysis įvykiai ir kokiu keliu eis šalys, kuriose pergales švente sukileliai.

\footnotetext{
${ }^{67}$ Lietuvos statistikos departamentas, „Eksportas, importas pagal valstybes“, 1407 2011, http://www.stat.gov. lt/lt/pages/view/?id=2795, 31082011.

${ }^{68}$ Žr.: Hosking G. A., The First Socialist Society: A History of the Soviet Union from Within, USA: Harvard University Press, 1992, p. 433.

${ }^{69}$ Česnakas G., „Arabų revoliucijų fone - ką galètų nuveikti Lietuva?“, Delfi.lt, 2202 2011, http://www.delfi. lt/news/ringas/lit/gcesnakas-arabu-revoliuciju-fone-ka-galetu-nuveikti-lietuva.d?id=42308423, 24022011.
} 
Prezidente Grybauskaite, kuri remiantis Lietuvos konstitucija sprendžia pagrindinius užsienio politikos klausimus ir vykdo užsienio politiką, arabų sukilimų fone daugiausia nuogąstavo dèl galimo neigiamo jų poveikio Lietuvos ir Europos energetiniam bei ekonominiam saugumui. Prezidente atkreipe demesi i neramumų Šiaurès Afrikoje įtaką naftos kainų kilimui ${ }^{70}$. Lietuvos krašto apsaugos ministre Rasa Juknevičienè baiminosi, kad sukilimai Vidurio Rytuose gali greitai ir radikaliai pakeisti saugumo situaciją Aljanso pašonëje. Anot jos, tai rodo, kad ir Lietuvos saugumo situacija gali pabloget $\mathrm{i}^{71}$.

Viešuose Lietuvos politinių lyderių komentaruose daugiausia dèmesio susilauke Vakarų karinis ịsitraukimas ị Libijos sukilimą. Jam, būdama NATO nare, Lietuva pritarè. Svarbiausi šalies užsienio politikos formuotojai ir vykdytojai (prezidentè, premjeras, užsienio reikalų ministras) vieningai palaikẻ JT Saugumo Tarybos rezoliuciją 1973. Visi jie akcentavo ribotas šalies galimybes prisidèti prie karinès misijos Libijoje vykdymo ir daugiau demesio skyre galimam humanitarinès pagalbos teikimui. Tiesa, net kalbèdami apie humanitarinę pagalbą, jie pažymėjo ribotas šalies galimybes.

Galima sakyti, kad menki Lietuvos ištekliai buvo svarbus ar net svarbiausias veiksnys, sukliudęs valstybei aktyviau prisideti prie Vakarų karinès operacijos Libijoje. Tačiau tai tikrai nebuvo vienintelis veiksnys, sulaikęs Lietuvą nuo aktyvesnio įsitraukimo ị konflikto Libijoje sprendimą. Santūrią Lietuvos laikyseną Vakaru karinès operacijos Libijoje atžvilgiu galima sieti su tuo, kad įvykiai šioje arabų šalyje neliečia tiesioginių Lietuvos interesų ${ }^{72}$. Be to, pasak Račiaus, palyginti pasyviai Lietuvos laikysenai Libijos klausimu turëjo įtakos ir apčiuopiamos naudos, kurią šalis galètu gauti aktyviau paremdama kitų Vakarų valstybių karinius veiksmus, nebuvimas $^{73}$. Paremdama $2001 \mathrm{~m}$. Afganistano ir $2003 \mathrm{~m}$. Irako karines intervencijas Lietuva tokią naudą aiškiai mate - didesnè tikimybe tapti NATO ir ES nare.

Pažymètina, kad susidomëjimą ir sumaištị vietos žiniasklaidoje sukèle tik prezidentès Grybauskaitès komentaras dèl situacijos Libijoje, kuris buvo išsakytas interviu Austrijos dienraščiui „Die Presse“ metu. Lietuvos prezidente pažymëjo,

\footnotetext{
${ }^{70}$ Prezidentes spaudos tarnyba, „Neramumai Šiaures Afrikoje - gressme ES ekonomikai“, 0803 2011, http:// www.president.lt/lt/spaudos_centras_392/pranesimai_spaudai/neramumai_siaures_afrikoje_gresme_es_ekonomikai.html?backlink=\%252Flt\%252Fpaieska\%252Fresults\%252Fp0.html, 01062011.

${ }^{71}$ Juknevičienè R., „Septyneri Lietuvos metai Aljanse - minèti nereikia pamiršti“', 2903 2011, http://www. kam.lt/lt/naujienos_874/archyvas_930/ziniu_archyvas_2011_metai/ziniu_archyvas_2011_-_03/krasto_apsaugos_ministre_rasa_jukneviciene_septyneri_lietuvos_metai_aljanse_mineti_nereikia_pamirsti.html?backlin

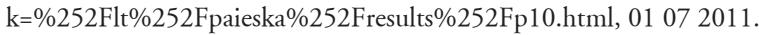

${ }^{72}$ Girnius K., „Užsienio politikos paieškos“, Alfa.lt, 0205 2011, http://www.alfa.lt/straipsnis/11207662/Uzsienio.politikos.paieskos=2011-05-02_08-03/, 02052011.

${ }^{73}$ Balsas.lt, „E. Račius: pretekstas pulti Libiją buvo, tik klausimas, ar pakankamas?“, Vilnius: UAB "Balsas.lt”, 2303 2011, http://www.balsas.lt/naujiena/530873/e-racius-pretekstas-pulti-libija-buvo-tik-klausimas-ar-pakankamas-video-foto, 26072011.
} 
kad Vakarų karinè operacija Libijoje peržengè JT suteiktą mandatą ${ }^{74}$. Grybauskaite taip pat pareiškẻ nesuprantanti, kodèl karinio įsikišimo prireikè būtent Libijoje. Pasak jos, Afrikos pietuose taip pat gausu diktatorių. Vietos politikos apžvalgininkai tokią Grybauskaites poziciją netrukus prilygino Rusijos premjero Vladimiro Putino pozicijai dèl Vakarų karinio ịsitraukimo ị sukilimą Libijoje ${ }^{75}$. Komentuodamas Grybauskaites interviu „Die Presse“ politologas Kęstutis Girnius konstatavo, kad Lietuvos politiniai lyderiai netinkamai derina pozicijas užsienio politikos klausimais ir todèl atrodo nesolidžiai ${ }^{76}$. Tokia jo iž̌valga visiškai pagrịsta. Savo pasisakymuose Libijos klausimu Lietuvos premjeras Andrius Kubilius ir krašto apsaugos ministre Juknevičienè akcentavo NATO ir Vakarų solidarumo svarbą ${ }^{77}$. Galima sakyti, kad Grybauskaitès komentaras dèl Aljansui priklausančių valstybių veiksmų Libijoje iš tiesų prasilenkè su NATO solidarumu. Šis komentaras atrodo keistai ir dèl tos priežasties, kad Lietuva pritare tam, kad rezoliucijos 1973 igyvendinimo kovo pabaigoje imtųsi NATO.

Antra vertus, Grybauskaités pastebëjimas, kad Vakarų karinè operacija Libijoje peržengė JT suteiktą mandatą, nesusilauke didelio dèmesio užsienyje. Tai galima aiškinti tuo, kad Lietuva iš tiesų yra palyginti maža ir neįtakinga valstybè. Be to, verta pažymèti, kad Lietuvos prezidentès nuostata Libijos klausimu iš esmès atitiko įtakingos Vakarų valstybès, Vokietijos, oficialią laikyseną.

Kadangi Vidurio Rytai yra toli nuo Lietuvos sienų, Vidurio Rytų su Lietuva nesieja glaudūs istoriniai, politiniai ar ekonominiai ryšiai, tad arabų sukilimų poveikis Lietuvai turètų būti nedidelis ir netiesioginis. Dèl arabų sukilimų daugiausia

\footnotetext{
${ }^{74}$ Prezidentés spaudos tarnyba, „Prezidentes Dalios Grybauskaitès interviu Austrijos dienraččiui “Die Presse”: „Operacija Libijoje peržengia JT mandatą“, 2011, http://www.president.lt/lt/prezidento_veikla/prezidente_ziniasklaidoje/interviu_385/prezidentes_dalios_grybauskaites_interviu_austrijos_dienrasciui_die_presse_operacija_libijoje_perzengia_jt_mandata.html?backlink=\%252Flt\%252Fpaieska\%252Fresults\%252Fp0.html, 01 062011.

${ }^{75}$ Žr.: Navickaite R., „NATO kritikai - V.Putinas ir D.Grybauskaite“, IQ.lt, 3004 2011, http://iq.lt/ titulinis/d-grybauskaitei-uzkliuvo-nato-atakos-libijoje/, 01062011.

Prezidentès spaudos tarnyba, „, Neramumai Šiaurès Afrikoje - grèsmè ES ekonomikai“, Vilnius: Lietuvos Respublikos Prezidento kanceliarija, 08-03-2011, http://www.president.lt/lt/spaudos_centras_392/pranesimai_spaudai/neramumai_siaures_afrikoje_gresme_es_ekonomikai.html?backlink= $\% 252 \mathrm{Flt} \% 252 \mathrm{Fpaieska} \% 2$ 52Fresults\%252Fp0.html, 01062011.

${ }^{76}$ Žr.: Navickaite R., „NATO kritikai - V.Putinas ir D.Grybauskaite“, 3004 2011, http://iq.lt/titulinis/dgrybauskaitei-uzkliuvo-nato-atakos-libijoje/, 01062011.

${ }^{77}$ Vakarų ekspresas, „Andrius Kubilius: Lietuva prie veiksmų Libijoje neprisides“, 2303 2011, http://www. ve.lt/naujienos/lietuva/lietuvos-naujienos/andrius-kubilius-lietuva-prie-veiksmu-libijoje-neprisides-565420/, 0407 2011; Rasa Juknevičienė, „Septyneri Lietuvos metai Aljanse - minèti nereikia pamiršti“, 2903 2011, http://www.kam.lt/lt/naujienos_874/archyvas_930/ziniu_archyvas_2011_metai/ziniu_archyvas_2011_-_03/ krasto_apsaugos_ministre_rasa_jukneviciene_septyneri_lietuvos_metai_aljanse_mineti_nereikia_pamirsti.html?backlink=\%252Flt\%252Fpaieska\%252Fresults\%252Fp10.html, 0107 2011; Diena.lt (BNS), „R.Juknevičienė:NATO sausumos operacija Libijoje neįsivaizduojama“, Diena.lt, 0806 2011, http://www. diena.lt/naujienos/uzsienis/r-jukneviciene-nato-sausumos-operacija-libijoje-neisivaizduojama-357318/skelbimai/skelbimai/komentarai, 07072011.
} 
galètų nukentèti tik Lietuvos ekonominis ir energetinis saugumas, jei arabų sukilimai labai padidintų naftos kainą arba kitaip neigiamai atsilieptų ES ekonominei gerovei. Arabų sukilimai greičiausiai neturès dideles įtakos Lietuvos dalyvavimui "globaliame kare prieš terorą" ir vietos kontrteroristinems operacijoms. Didele tikimybè, kad dèl arabų sukilimų Lietuvos neužplūs imigrantai iš Vidurio Rytų. Pastarųjų kelionès tikslas tradiciškai yra turtingesnès ES valstybès.

Lietuvos saugumui arabų sukilimai iš tiesų aktualūs galettu būti iš esmès tik dèl Vidurio Rytų regiono ribų nepaisančio domino principo, kurị jie gali sukelti. Lietuvos saugumo ir užsienio politikos formuotojus daugiausia dominančiu valstybių sąraše yra nemažai šalių, kuriose politine ir socialine įtampa pasiekusi lygị, panašu į tą, kuris sukèlè sukilimus Vidurio Rytų valstybèse. Tuniso, Egipto ar Libijos tipo sukilimams iš esmés palanki situacija yra daugelyje Vidurio Azijos valstybių. Pavyzdžiui, Kirgizija, Tadžikistanas ir Uzbekistanas patenka į „Foreign Policy “ ir „The Fund for Peace“ sudarytą vadinamųjų žlugusių valstybių, t. y. valstybiu, kuriose saugumo situacija ypač nestabili, sąrašą ${ }^{78}$. Koks nors iš pirmo žvilgsnio ne itin reikšmingas politinio protesto aktas gali parodyti, kad sukilimui prieš Aleksandro Lukašenkos autokratinį režimą jau pribrendusi didelè dalis Baltarusijos visuomenès. Visai netikètai gali paaiškèti, kad Vladimiro Putino ir jo bendražygiu sukurtas policinis režimas Rusijoje irgi tèra milžinas molinėmis kojomis.

Baigiant reikia pažymèti, kad masinių ir galingą politinị užtaisą turinčių protestų formą igaunantys sukilimai nèra būdingi tik Vidurio Rytų regionui. Mohhamedas Bouazizis nèra pirmas ir tikrai ne paskutinis protesto vardan viešai susideginęs asmuo. Todèl po visus netikètai Vidurio Rytus užklupusių sukilimų Lietuvos, taip pat ir kitų Vakarų valstybių saugumo ekspertai, gali pagrįstai tikètis naujų netikètų sukilimų netikètose vietose.

\section{Išvados}

Arabų sukilimu poveiki Vakarų ir Lietuvos saugumo interesams sunku tiksliai įvertinti. Sukilimai yra dar nepasibaigę procesai. Daugeliu atveju arabų sukilimų baigtis neaiški. Juose dalyvaujantys žaidèjai sunkiai nuspëjami. Tikrosios arabų sukilimų pasekmès Vakarų ir Lietuvos saugumo interesams gali paaiškèti tik po kelerių metų ar po kelių dešimtmečių.

Kol kas aišku tiek, kad arabu sukilimai - strategines svarbos ịvykiai. Jie keičia jegų balansą Vidurio Rytų regione. Šis regionas bent jau trumpuoju periodu tampa mažiau stabilus. İtakingiausias Vakarų valstybes tai verčia peržiūrèti

\footnotetext{
${ }^{78}$ Žr.: Foreign Policy, „The Failed States Index 2011“, http://www.foreignpolicy.com/articles/2011/06/17/2011_failed_states_index_interactive_map_and_rankings, 31082011.
} 
savo didžiąsias strategijas, kurios susiję su Vidurio Rytais. Vašingtone, Londone ir Paryžiuje užsienio politikos strategai suka galvas dẻl to, kokius santykius toliau palaikyti su tomis arabų valstybemis, kurias vis dar valdo diktatoriai, ir sukilimu paveiktomis šalimis, kurios nusikrate savo autokratinių lyderių.

Akivaizdu, kad arabų sukilimai neatneš Vakarams nusiraminimo ir neleis atitraukti savo demesio nuo tolesnių ịvykių šiame regione. Panašu, kad dèl arabų sukilimų Vakarams gali būti sunkiau siekti nenutrūkstamo Vidurio Rytų regiono naftos tekejjimo ị Vakarus. Sudètingesnis gali būti Vakarų ir arabų valstybių dialogas įvairiais saugumo klausimais. Šiuo atveju ypač gali nukenteti Vakarų ir arabų valstybių bendradarbiavimas kovos prieš terorizmą srityje.

Lietuvos, skirtingai nuo kai kurių kitų Vakarų valstybių, su Vidurio Rytų regiono valstybėmis nesieja stiprūs istoriniai, politiniai ar ekonominiai ryšiai. Tai padeda paaiškinti, kodèl arabų sukilimai Lietuvos saugumui neturi didelio tiesioginio poveikio. Galimai sudètingesnis Vakarų ir arabų valstybių bendradarbiavimas ịvairiais saugumo klausimais, ịskaitant kovą prieš terorizmą, Lietuvos saugumo neturètų labai paveikti.

Lietuvos politiniams lyderiams aktualiausias yra arabų sukilimų poveikio šalies ekonominiam ir energetiniam saugumui klausimas. Kiek sukilimai Vidurio Rytuose gali pakenkti nuo Rusijos energetinių išteklių priklausomai Lietuvos ekonomikai? Apskritai Lietuvos politinių lyderių pozicijos dèl arabų sukilimų analize leidžia teigti, kad oficialią šalies laikyseną sukilimų atžvilgiu lemia realioji politika (realpolitik), o ne idealistiškai nusiteikę liberalizmo ir demokratijos šalininkai. Turint omenyje, kad Lietuva - palyginti maža valstybè su menkais ištekliais, kuriuos gali skirti savo saugumo ir užsienio politikai igyvendinti, tai nèra labai blogai.

Arabų sukilimai iš tiesų svarbūs Lietuvai galètų būti, jei paskatintų domino efektą kituose regionuose ar valstybese, kurie kur kas svarbesni Lietuvos saugumui. Po netikètų sukilimų Vidurio Rytuose atsiranda daugiau pagrindo tikètis socialinių ir politinių neramumų Lietuvos kaimynystëje (Baltarusijoje ir Rusijoje) bei Vidurio Azijos valstybèse. Šiose valstybèse gyvuojantys politiniai režimai pagal daugelį vertinimo kriteriju primena režimus, kurie egzistavo Tunise, Egipte ir Libijoje.

Vilnius, 2011 m. liepa-rugpjūtis 